\title{
EFEKTIVITAS INSEKTISIDA DALAM MENEKAN PERKEMBANGAN POPULASI DAN SERANGAN LIRIOMYZA, SP PADA TANAMAN BAWANG MERAH LOKAL PALU (Allium cepa L. $x$ Wakegi Araki) DI DESA GUNTARANO KECAMATAN TANANTOVEA KABUPATEN DONGGALA
}

\author{
THE EFFECTIVENESS OF INSECTICIDE IN PRESSING THE \\ DEVELOPMENT OF POPULATION AND ATTACKS OF LIRIOMYZA SP \\ ON LOCAL PALU ONIONS (Allium cepa L.x Wakegi Araki) \\ AT GUNTARANO VILLAGE TANANTOVEA SUB-DISTRICT \\ DONGGALA DISTRICT
}

\author{
$\operatorname{Arfan}^{1 *}$, Sri Sudewi $^{1}$, Mihwan Sataral ${ }^{2}$, Sumarni $^{1}$, Vevi Rosiani ${ }^{1}$, Mumfahida $^{1}$, Karmila Soar $^{1}$ \\ ${ }^{1}$ Program Studi Agroteknologi, Fakultas Pertanian, Universitas Alkhairaat, Jl. Diponegoro, Fakultas \\ Pertanian Universitas Alkhairaat, Palu 94221, Indonesia (11pt) \\ ${ }^{2}$ Program Studi Agroteknologi Fakultas Pertanian Universitas Tompotika Luwuk
}

\begin{abstract}
ABSTRAK
Penelitian ini bertujuan untuk mengkaji efektivitas dari beberapa insektisida terhadap perkembangan populasi dan serangan Liriomyza sp pada pertanaman bawang merah lokal palu. Penelitian dilaksanakan pada bulan Februari sampai April 2017 di Desa Guntarano (Sentra penanaman tanaman bawang merah) Kecamatan Tanantovea, Kabupaten Donggala. Penelitian menggunakan Rancangan Acak Kelompok (RAK) yang terdiri atas empat perlakuan yaitu Po.Kontrol; P1. Abamectin; P2. Azadiractin; P3. Dimohipo. Setiap perlakuan diulang sebanyak tiga kali sehingga di peroleh perlakuan sebanyak 12 kali percobaan. Hasil penelitian menunjukkan bahwa perlakuan insektisida berpengaruh terhadap perkembangan populasi imago Liriomyza sp yang beragam pada berbagai tingkat umur tanaman. Hasil pengamatan pada umur tanaman 5 dan 6 MST menunjukkan bahwa insektisida abamectin efektif menekan perkembangan populasi larva Liriomyza sp dibandingkan dengan perlakuan insektisida Azadiractin, Dimohipo dan tanpa perlakuan.
\end{abstract}

Katakunci : Liriomyza sp, Insektisida, Bawang Merah

\section{ABSTRACT}

This study aimed to examine the effectiveness of some insecticides on the population development and attack Liriomyza sp on local Palu onions. The research conducted from Februari to April 2017, at Guntarano village, Tanantovea Sub-District, Donggala District. The study used Randomized Block Design (RAK) consisting of four treatments, namely Po.Control; P1. Abamectin; P2. Azadiractin; P3. Dimohipo. Each treatment was repeated three times so that 12 treatments were obtained. The results showed that the insecticidal treatment had an effect on the development of the varied Liriomyza sp. Adult population at various plant age levels. Observations on plant age 5 and 6 of MST showed that abamectin insecticides were effective in suppressing the growth larvae populations of Liriomyza sp compared with the treatment of Azadiractin, Dimohipo and non-treated insecticides.

Keywords: Liriomyza sp, Insectiside, Red Onion 


\section{Pendahuluan}

Kendala utama yang dihadapi petani Desa Guntarano dalam budidaya tanaman bawang merah lokal palu (Allium cepa L.x Wakegi Araki) adalah adanya serangan Organisme Pengganggu Tanaman (OPT) hama Lalat Pengorok Daun (Liriomyza sp.). Di Lembah palu terdapat tiga spesies Liriomyza, sp yaitu Liriomyza chinensis, L. sativae, dan L. huidobrensis (Shahabuddin et al., 2013; Arfan et al., 2016). diantara ketiga spesies tersebut, $L$. chinensis dan $L$. sativae merupakan hama yang menyerang tanaman bawang (Allium sp.) dan mendominasi komposisi spesies pengorok daun di lembah palu (Shahabuddin et al., 2014)

Hama Liriomyza sp tergolong baru keberadaannya dalam budidaya tanaman bawang merah di lembah palu, yang ditemukan pada tahun 2005 (Shahabuddin et al., 2013). Serangan Liriomyza, spp menunjukkan gejala berupa bintik-bintik (Murphy \& LaSalle, 1999), akibat tusukan ovipositor dan aktivitas makan dari larva pada jaringan daun (Herlinda et al., 2006; Rustam, 2009), liang korokan berbentuk linear, mengular (Mujica and Kroschel 2013), membentuk spiral panjang dan berkelit (Sembel, 2011), selanjutnya daun mengering dan berwarna coklat seperti terbakar (Herlinda et al., 2005) hingga gagal panen (Spencer, 1989). Beberapa peneliti melaporkan tingkat kerusakan yang diakibatkan oleh hama pengorok daun bisa mencapai $60-70 \%$ (Rauf et al, 2000), kehilangan hasil dapat mencapai 20-80\% (Nonci \& Muis, 2011; Shahabuddin et al., 2012; Shahabuddin et al.,2013).

Upaya yang dilakukan oleh petani dalam menekan serangan OPT Liriomyza dengan menggunakan insektisida kimia. Beberapa insektisida yang digunakan diantaranya abamectin, azadiractin dan dimohipo (Arfan et al., 2018). Aplikasi insektisida kimia yang dilakukan oleh petani sifatnya preventif, melakukan penyemprotan setiap minggu sebanyak 2 kali (Arfan et al., 2016). Penggunaan insektisida khususnya insektisida organik sintetik sangat manjur untuk mengendalikan hama dan membantu dalam mempertahankan produksi dan kualitas hasil pertanian (Skevas et al, 2014;

\footnotetext{
${ }^{*}$ Penulis Korespondensi.

E-mail: arfanilmu@gmail.com

Telp: +62-85228976417
}

Soedijo et al, 2015).

Penggunaan insektisida yang dilakukan secara intensif, meluas dan tidak bijaksana, ditengarai sebagai penyebab terganggunya kestabilan ekosistem (Matthews 2017; Leppla et al., 2018) terjadinya pergeseran terhadap keseimbangan ekologi di dalam agroekosistem, terbunuhnya beberapa musuh alami (Shearer et al. 2016; Santos et al., 2017). Berdasarkan hal tersebut di atas, maka dilakukanlah penelitian tentang respons liriomyza spp terhadap berbagai insektisida pada tanaman bawang merah di Desa Guntarano. Penelitian ini bertujuan untuk mengkaji efektivitas dari beberapa insektisida terhadap perkembangan populasi dan serangan Liriomyza sp pada pertanaman bawang merah lokal palu. Penelitian ini diharapkan dapat berguna sebagai bahan informasi dasar untuk mengetahui perkembangan serangan hama Liriomyza, spp dan cara pengendaliannya, sekaligus sebagai bahan informasi untuk penelitian berikutnya.

\section{Metode Penelitian}

Penelitian ini dilaksanakan di Desa Guntarano (Sentra penanaman tanaman bawang merah) Kecamatan Tanantovea, Kabupaten Donggal. Pada bulan Februari sampai bulan April 2017. Pelaksanaan penelitian dilaksanakan dengan Rancangan Acak Kelompok (RAK) yang terdiri atas empat perlakuan. Adapun taraf perlakuan yaitu: $\mathrm{Po}=$ Kontrol; $\mathrm{P} 1=$ Abamectin; P2=Azadiractin; P3=Dimohipo. Dengan dosis penyemprotan 500 liter / ha. Setiap perlakuan diulang sebanyak tiga kali sehingga diperoleh perlakuan sebanyak 12 kali percobaan. Penelitian ini dilaksanakan dengan beberapa tahap sebagai berikut: a). Pembuatan Perangkap Perekat Likat Kuning. Perangkap perekat likat kuning terbuat dari potongan pipa paralon yang berbentuk silinder (garis tengah $6 \mathrm{~cm}$ dan tinggi $30 \mathrm{~cm}$, permukaan luar dicat dengan warna kuning. Selanjutnya pipa paralon dibungkus dengan plastik bening dan permukaan plastik diolesi lem tikus cap gadjah sebagai perekat serangga; b). Sebelum dilakukan penanaman terlebih dahulu dilakukan pengolahan tanah dengan menggunakan hand tractor, selanjutnya diratakan dan dibagi menjadi tiga kelompok. Setiap petak berukuran, panjang $350 \mathrm{~cm}$, lebar $120 \mathrm{~cm}$; c). Penanaman bawang merah pada umumnya dilakukan melalui umbi. Sebelum ditanam, kulit luar umbi bibit yang mengering dibersihkan. Umbi bibit bawang merah ditanam 


\section{Jurnal Agrotech 8 (1) 23-28}

sesuai dengan persyaratan agronomis, yakni sebelum ditanam terlebih dahulu ujung umbi di potong kira-kira $1 / 4$ bagian, hal ini dilakukan untuk mempercepat pertumbuhan tunas dan merangsang tumbuhnya umbi samping (Soetiarso, 2007); d). Aplikasi Pupuk kandang dilakukan seminggu sebelum dilaksanakan penanaman, diditabur secara merata di atas bedengan yang telah disiapkan selanjutnya aplikasi pupuk kimia diberikan sesuai dengan dosis anjuran yaitu urea $100 \mathrm{~kg} / \mathrm{ha}, \mathrm{ZA} 200$ kg/ha, KCL 100 kg/ha dan SP-36 300 kg; e).

Pemeliharaan meliputi pemberian air dilakukan dengan cara genangan dalam parit disekitar petak percobaan dengan intensitas setiap hari selama satu minggu untuk merangsang pertumbuhan awal tanaman dan selanjutnya pemberian air dilakukan dua hari sekali dalam kondisi kapasitas lapang hingga dua minggu sebelum panen. Pengendalian gulma dilakukan satu minggu sebelum tanam untuk menghambat pertumbuhan awal dengan metode pengendalian secara mekanik menggunakan koret dan pengendalian fisik dengan mencabut setiap rumput yang tumbuh pada media tumbuh atau bedengan penanaman hingga menjelang panen. f). Perlakuan insektisida diaplikasikan secara terjadwal sekali seminggu. Penyemprotan dimulai pada umur 2 MST dan berakhir 7 hari sebelum panen.

\section{Variabel Pengamatan}

a. Populasi Imago Liriomyza sp

Pengamatan populasi imago Liriomyza sp dilakukan dengan mengamati populasi imago yang tertangkap setiap minggu dari umur tanaman 3 MST- 6 MST.

b. Populasi larva Liriomyza sp

Pengamatan populasi larva Liriomyza sp, diamati secara langsung pada umur 5 MST 6 MST.

c. Persentase serangan Liriomyza sp

Persentase serangan liriomyza, diamati secara langsung dengan menghitung jumlah rumpun tanaman yang terserang Liriomyza sp.

Untuk menghitung persentase serangan

Liriomyza, spp dilakukan dengan tipe kerusakan mutlak, menggunakan persamaan berdasarkan Pedigo \& Buntin (2003):

$P=\frac{n}{N} x 100 \%$ Keterangan:

$\mathrm{P}=$ Persentase serangan Liriomyza, spp

$\mathrm{n}=$ Jumlah daun bawang merah yang menunjukkan gejala totol-totol putih

$\mathrm{N}=$ Jumlah daun bawang merah (rumpun) yang diamati
e-ISSN : 2621-7236

p-ISSN : 1858-134X

\section{Hasil dan Pembahasan}

\section{Populasi Imago Liriomyza sp}

Berdasarkan hasil pengamatan pada pertanaman bawang merah lokal palu yang diberi berbagai perlakuan insektisida menunjukkan data perkembangan populasi imago Liriomyza sp yang beragam pada berbagai tingkat umur tanaman. Perkembangan populasi Imago Liriomyza sp pada bawang merah lokal palu pada umur 3-6 MST (Gambar 1) menunjukkan bahwa pada umur 3 MST populasi imago Liriomyza sp terbanyak pada tanaman bawang merah tanpa perlakuan insektisida kemudian terendah pada tanaman bawang merah yang diaplikasi dengan insektisida abamektin, selanjutnya populasi imago Liriomyza sp meningkat seiring dengan pertambahan umur tanaman. Shahabuddin (2012) yang mengemukakan bahwa awal serangan lalat penggorok daun pada tanaman bawang merah mulai terjadi pada umur 2-3 MST, dan berlangsung hingga fase pematangan umbi umur 51-65 HST. Beradasarkan uji Tukey (Tabel 1) menunjukan bahwa perlakuan insektisida abamectin sangat berpengaruh terhadap populasi imago Liriomyza sp. Hasil penelitian Saad et al., (2007) menunjukan bahwa abamectin sangat efektif menekan populasi Liriomyza. Faktor yang mungkin berpengaruh terhadap perkembangan populasi Liriomyza sp disebabkan oleh perilaku petani dalam mengendalikan OPT menggunakan insektisida kimia dengan frekuensi penyemprotan 2-3 kali setiap minggu dengan harapan dapat menekan laju perkembangan hama dengan cepat, namun saat ini beberapa insektisida kimia yang digunakan petani sudah menurun daya bunuhnya karena adanya perubahan atau proses adaptasi serangga Liriomyza sp tersebut.

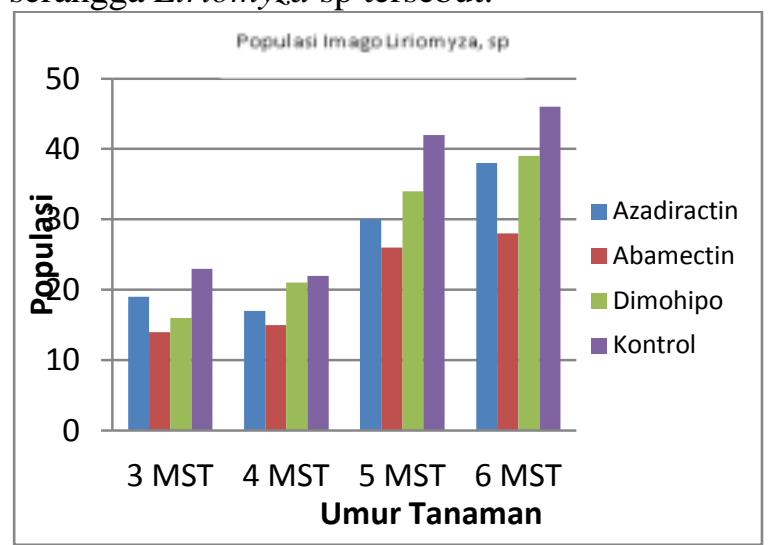

Gambar 1. Populasi Imago Liriomyza sp pada bawang merah lokal palu pada 3-6 MST dengan perlakuan berbagai insektisida 
Tabel 1. Rerata jumlah populasi imago Liriomyza sp pada berbagai perlakuan insektisida

\begin{tabular}{lc}
\hline Perlakuan & Rata-rata jumlah populasi \\
\hline Kontrol & $33.25^{\mathrm{a}}$ \\
Azadiractin & $26.00^{\mathrm{ab}}$ \\
Abamectin & $20.75^{\mathrm{b}}$ \\
Dimohipo & $27.50^{\mathrm{ab}}$ \\
\hline
\end{tabular}

Keterangan : Angka yang diikuti oleh huruf yang sama tidak berbeda nyata pada taraf uji Tukey $1 \%$.

\section{Populasi Larva Liriomyza sp}

Berdasarkan hasil pengujian berbagai jenis insektisida dan tanpa perlakuan insektisida terhadap populasi larva Liriomyza sp menunjukkan jumlah populasi larva yang bervariasi. Hasil pengamatan pada umur tanaman 5 MST menunjukkan bahwa insektisida abamectin efektif menekan perkembangan populasi larva Liriomyza sp dibandingkan dengan perlakuan insektisida Azadiractin, Dimohipo dan tanpa perlakuan dengan jumlah larva yang ditemukan pada tanaman yang diaplikasi dengan insektisida abamectin sebanyak 0,15 ekor per pengamatan dibandingkan dengan tanpa perlakuan sebesar 0,5 ekor per pengamatan. Hasil penelitian Weintraub (1999) menunjukan bahwa aplikasi abamectin secara signifikan mengurangi larva Liriomyza. Kemampuan insektisida abamectin dalam menekan perkembangan larva Liriomyza, spp, hal ini mungkin disebabkan oleh cara kerja dari insektisida abamectin 18 EC bekerja secara kontak, lambung dan sistemik (Reddy et al, 2014). Penggunaan insektisida abamectin menyebabkan tidak berfungsinya beberapa sel-sel pada bagian pencernaan serangga khususnya pada midgut (Aljedani, 2017), dan juga bekerja dengan cara menghambat transmisi syaraf (Kola et al., 2015) sehingga menyebabkan terjadinya paralisis.

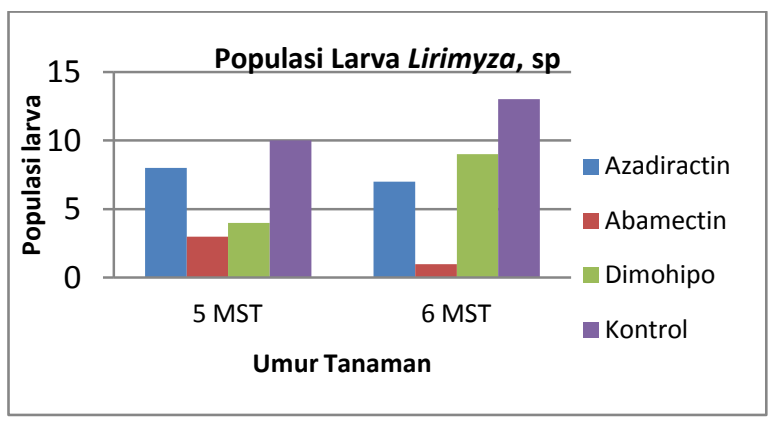

Gambar 2. Populasi Larva Liriomyza sp. pada bawang merah lokal palu dengan perlakuan berbagai insektisida

\section{Persentase Serangan}

Berdasarkan hasil pengujian dari empat jenis insektisida terhadap persentase serangan menunjukkan bahwa insektisida abamectin berpengaruh terhadap intensitas serangan Liriomyza sp. Dari hasil pengamatan populasi Liriomyza sp sangat tinggi, sehingga rata-rata persentase serangan Liriomyza sp pada pengamatan 3 MST antara 62,96-85,32\% selanjutnya terjadi penurunan serangan seiring dengan dilakukannya aplikasi perlakuan insektisida.

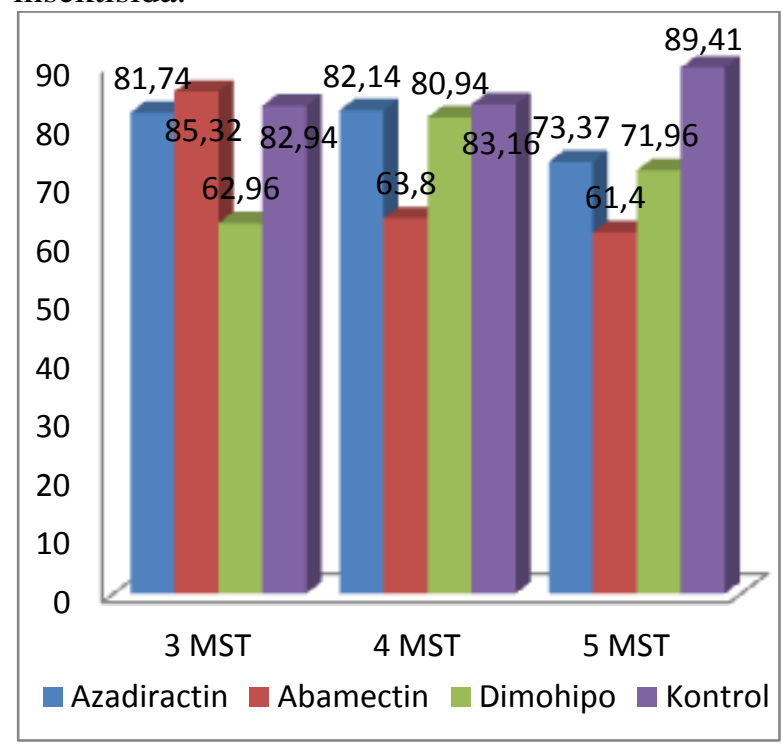

Gambar 3. Tingkat intensitas serangan Liriomyza sp pada pengamatan 3-5 MST dengan perlakuan berbagai insektisida.

Aplikasi insektisida abamectin memberikan pengaruh terhadap persentase serangan. Perlakuan aplikasi insektisida abamectin dapat menurunkan persentase serangan lalat pengorok daun menghasilkan ratarata tingkat serangan lebih rendah dibandingkan dengan perlakuan lainnya. Hasil penelitian Ramesh dan Ukey (2007) menunjukan abamektin efektif dalam mengurangi intensitas serangan Liriomyza. Tingginya intensitas serangan Liriomyza sp pada setiap pengamatan dengan berbagai perlakuan insektisida (Gambar 3) menunjukan cukup rentannya varietas bawang lembah palu terhadap serangan lalat penggorok daun. sehingga lalat penggorok daun tetap menyerang tanaman tersebut walaupun sudah dilakukan aplikasi insektisida. 
Jurnal azrotech 8 (1) 23-28

\section{Kesimpulan}

Berdasarkan hasil penelitian, dapat ditarik kesimpulan sebagai berikut:

1. Hasil pengamatan pada umur tanaman 5 dan 6 MST menunjukkan bahwa Insektisida abamectin efektif menekan perkembangan populasi larva dan imago Liriomyza sp dibandingkan dengan perlakuan insektisida Azadiractin, Dimohipo dan tanpa perlakuan.

2. Insektisida abamectin efektif menekan serangan lalat pengorok daun menghasilkan rata-rata persentase tingkat serangan lebih rendah dibandingkan dengan perlakuan lainnya.

\section{Daftar Pustaka}

Aljedani, D.M. 2017. Effects of abamectin and deltamethrin to the foragers honeybee workers of Apis mellifera jemenatica (Hymenoptera: Apidae) under laboratory conditions. Saudi Journal of Biological Sciences 24(5): 1007-1015.

Arfan, A. Alam, Basri. Z, and Toana. H., 2018. Effect of Chemical Insecticides on the Arthropod Diversity in the Agroecosystem of Red Onion Crops. Asian J. Crop Sci. 10 (3): 107-114.

Arfan., Ratnawati., Shahabuddin, 2016. Distribusi dan populasi hama pengorok daun (Liriomyza, SPP) pada sentra penanaman bawang merah di Lembah Palu. Prosiding. PEI Cab Palu.

Herlinda S, Jaya A, Pujiastuti Y, Rauf A. 2006. Kapasitas reproduksi, lama hidup, dan perilaku pencarian inang tiga spesies parasitoid Liriomyza sativae. Hayati Journal of Biosciences. 13(4):156-160.

Herlinda S, Rosalina LP, Pujiastuti Y, Sodikin E, Rauf A. 2005. Populasi dan serangan Liriomyza sativae (Blanchard) (Diptera:Agromyzidae), serta potensi parasitoidnya pada pertanaman ketimun. Jurnal HPT Tropika. 5 (2) 73-81.

Kola VSR, Renuka P, Madhav MS, Mangrauthia SK. 2015. Key enzymes and proteins of crop insects as candidate for RNAi based gene silencing. Front. Physiol. 6(119):1-15.

Leppla NC, Johnson MW, Merritt JL, Zalom FG.
e-ISSN : 2621-7236

p-ISSN : 1858-134X

2018. Applications and trends in commercial biological control for arthropod pests of tomato. Sustainable Management of Arthropod Pests of Tomato, Pp 283-303. Academic Press.

Matthews, G. 2017.Integrated Pest Management: Practice. Encyclopedia of Applied Plant Sciences. Pp 98-102. Academic Press.

Mujica, N., Kroschel, J. 2013. Pest intensity-crop loss relationships for the leafminer fly Liriomyza huidobrensis (Blanchard) in different potato (Solanum tuberosum L.) varieties. Crop Protection. 47: 6-16.

Murphy, S.T and J. LaSalle. 1999. Balancing biological control strategies in the IPM of New World Invasive Liriomyza Leafminers in field vegetable crops. Biocontrol News and Information. 20(3): 91-104.

Nonci. N, Muis A. 2011. Bioekologi dan pengendalian pengorok daun Liriomyza chinensis Kato (Diptera : Agromyzidae) pada bawang merah. Jurnal Litbang Pertanian. 30(4):148-155.

Ramesh, R. and Ukey, S.P. 2007. Bio-efficacy of botanicals, microbials and newer insecticides in the management of tomato leaf miner, Liriomyza trifolii (Burgess). Int J Agric Sci. 3 (1): 154-156.

Rauf A, Shepard BM, Johnson MW. 2000. Leafminers in vegetables, ornamental plants and weeds in Indonesia: Surveys of host crops, species composition and parasitoids. International Journal of Pest Management. 46(4):257-266.

Reddy DS, Nagaraj R, Latha MP, Chowdary R. 2014. Comparative evaluation of novel acaricides against two spotted spider mite. Tetranychus urticae Koch. infesting cucumber (Cucumis sativus) under laboratory and green house conditions. The Bioscan. 9(3): 1001-1005.

Rustam R, Raun A, Maryana N, Pudjianto, Danang. 2009. Studi lalat penggorok daun Liriomyza spp pada pertanaman bawang daun dan parasitoid Opius chromatomyiae. J. HPT Tropika. 9(1):22-31. 


\section{Jurnal Oazrotech 8 (1) 23-28}

Saad AS, Massoud MA, Abdel-Megeed AA, Hamid NA, Mourad AK, Barakat AS. 2007. Abamectin, pymetrozine and azadirachtin sequence as a unique solution to control the leafminer Liriomyza trifolii (Burgess) (Diptera: Agromyzidae) infesting garden beans (Phaseolus vulgaris L.) in Egypt. Commun Agric Appl Biol Sci. 72(3):583593.

Santos KFA, Zanardi OZ, de Morais MR, Jacob CRO, de Oliveira MB, Yamamoto PT. 2017. The impact of six insecticides commonly used in control of agricultural pests on the generalist predator Hippodamia convergens (Coleoptera: Coccinellidae). Chemosphere. 186: 218226.

Sembel DT, Manoi T, Tulung M, Pongoh J, Meray M, Ratulangi M, 2011. Pertumbuhan Liriomyza sativae Blancard dan Nesidiocoris tenuis Reuter pada beberapa galur serta varietas tomat. Eugenia. 17(1):1-9

Shahabuddin, Anshary A, Gellang A. 2012. Tingkat serangan dan jenis lalat pengorok daun pada tiga varietas bawang merah di Sulawesi Tengah. J. HPT Tropika 12(2): 153-161.

Shahabuddin, Pasaru F, Hasriyanty, 2013. Pengorok daun dan potensi parasitoidnya pada berbagai jenis tanaman sayuran di Lembah Palu, Sulawesi Tengah. J. HPT Tropika. 13(2):133-140.
e-ISSN : 2621-7236

p-ISSN : 1858-134X

Shahabuddin, Yunus M, Pasaru F, Hasriyanty. 2014. Pengembangan pengendalian berkelanjutan Liriomyza chinensis pada tanaman bawang merah di Sulawesi Tengah. Prosiding Seminar Nasional dan Lokakarya FKPTPI, Pokja Wilayah Indonesia Timur, Tanggal 22-23 Mei 2014:73-82.

Shearera PW, Amarasekare KG, Castagnoli SP, Beers EH, Jones VP, Mills NJ. 2016. Large-plot field studies to assess impacts of newer insecticides on non-target arthropods in Western U.S. orchards. Biological Control. 102: 26-34.

Skevas T, Swinton SM, Meehan TD, Kim TN, Gratton C, Egbendewe-Mondzozo, A. 2014. Analysis-Integrating agricultural pest biocontrol into forecasts of energy biomass production. Ecological Economics. 106:195-203.

Soedijo, S., M.I. Pramudi., 2015. Diversity of spider arthropods on rice rainfed in South Kalimantan. Pros Sem Nas Masy Biodiv Indon. 1(6): 1307-1311.

Spencer KA. 1989. Leaf miners. In Plant Protection and Quarantine, Vol. 2, Selected Pests and Pathogens of Quarantine Significance (ed Kahn RP). CRC Press, Boca Raton, pp. 77-98.

Weintraub PG. 1999. Effects of cyromazine and abamectin on the leafminer, Liriomyza huidobrensis and its parasitoid, Diglyphus isaea in celery. Ann. Ap. Biol. 135(3): 547554. 